\title{
Desain dan Fabrikasi Antena Rhombic untuk Aplikasi Telemetri Data pada Frekuensi 433 $\mathrm{MHz}$
}

\author{
Agus Salim $^{1}$, Heru Wijanarko" $^{*}$, Kamarudin $^{2}$, dan Siti Aisyah ${ }^{1}$ \\ ${ }^{1}$ Politeknik Negeri Batam, Batam, Indonesia
}

*Email: wijanarko@polibatam.ac.id

\begin{abstract}
Abstrak-Perkembangan riset komunikasi modern saat ini mengarah pada komunikasi satelit. Telemetri data atmosfer yang kemudian dikirimkan ke ground segment menjadi bagian dari komunikasi satelit. Untuk mendukung sistem komunikasi tersebut, diperlukan antena yang baik agar dapat menerima data pada jangkauan yang jauh. Pada penelitian ini telah dilakukan proses desain, fabrikasi, pengukuran, dan pengujian antena Rhombic untuk mendukung aplikasi telemetri data. Desain antena diawali dengan melakukan perhitungan sesuai spesifikasi yang diinginkan dan dilanjutkan dengan simulasi menggunakan software 4nec2. Hasil pengukuran antena yang telah difabrikasi menunjukkan adanya pergeseran frekuensi dari $433 \mathrm{MHz}$ menjadi 416 MHz. Pada frekuensi $416 \mathrm{MHz}$, frekuensi optimum antena, terukur nilai VSWR sebesar 1,53 dan return loss sebesar $-13,45 \mathrm{~dB}$. Kemudian dilakukan pengujian secara langsung dengan cara menjadikan antena Rhombic hasil fabrikasi menjadi antena penerima dan modul radio 3DR sebagai sistem pemancar. Hasil pengujian langsung (outdoor) diperoleh jangkauan antena dapat menerima data hingga 3,94 kilometer. Secara umum, antena Rhombic hasil fabrikasi bekerja dengan baik pada frekuensi optimum, namum masih terdapat ruang untuk dilakukan perbaikan dan pengembangan kedepannya.
\end{abstract}

Kata Kunci: antena rhombic, telemetri data, $433 \mathrm{MHz}$

\section{Pendahuluan}

PENGAMATAN data atmosfer dan mengirimkannya ke stasiun bumi (ground segment) merupakan bagian dari teknologi dan riset pada sistem komunikasi satelit. Komunikasi satelit akan menjadi salah satu fokus dalam riset komunikasi modern. Telemetri data dari sensor menggunakan media udara sebagai perantara. Untuk dapat menerima data atmosfer yang dikirim oleh payload, dibutuhkan suatu sistem penerima atau receiver pada ground segment, dimana antena merupakan salah satu bagian pentingya. Semakin bagus antena yang digunakan, semakin baik pula sinyal yang diterima.

Antena unidirectional dapat digunakan untuk mengatasi permasalahan kurang optimalnya penerimaan data. Antena Rhombic, yang merupakan salah satu jenis antena polygonal loop [1], adalah antena unidirectional yang memiliki gain cukup besar. Antena Rhombic memiliki kelebihan seperti: menghasilkan transmisi yang efektif; mudah untuk menggabungkan beberapa antena Rhombic; konstruksinya sederhana; memiliki impedansi input dan pola radiasi yang konstan; dan dapat mengatasi permasalahan pada grounding terminasi antena V [2]. Pada penelitian antena Rhombic sebelumnya, antena ini telah diimplementasikan pada aplikasi GPS [3], infra merah [4], RFID [5], Wireless LAN, dan WiMAX [6].

Pada artikel ini, penulis akan membahas tentang desain antena Rhombic yang dirancang untuk komunikasi telemetri data pada frekuensi $433 \mathrm{MHz}$. Sebelumnya, penulis telah melakukan beberapa penelitian yang berkaitan dengan telemetri data. Penelitian akuisisi data parameter lingkungan [7], dilakukan tanpa menggunakan antena dan fokus pada kecepatan data processing. Pada [8], dengan menggunakan modul radio transceiver 3DR, data gambar ditransmisikan pada kanal UHF secara real time. Kemudian pada tahun 2020, didesain dan diimplementasikan antena Quadrifilar Helix [9] untuk mengoptimalkan jangkauan pengiriman data. Sehingga, sebagai kelanjutan dari penelitian tersebut, antena Rhombic dirancang dan difabrikasi untuk melihat potensi jangkauan komunikasi yang lebih optimal.

\section{DASAR TEORI}

\section{A. Struktur Dasar Antena Rhombic}

Dua buah antena $\mathrm{V}$ dapat dihubungkan pada ujungnya yang terbuka untuk membentuk antena diamond atau Rhombic. Bentuk V yang terbalik dihubungkan ke ground melalui resistor. Seperti halnya antena V, pola antena Rhombic dapat dikontrol dengan memvariasikan panjang elemen, sudut antar elemen, dan bidang belah ketupat [1]. Berikut gambar 1 menunjukkan struktur antena Rhombic yang disusun dari dua antena $\mathrm{V}$. 


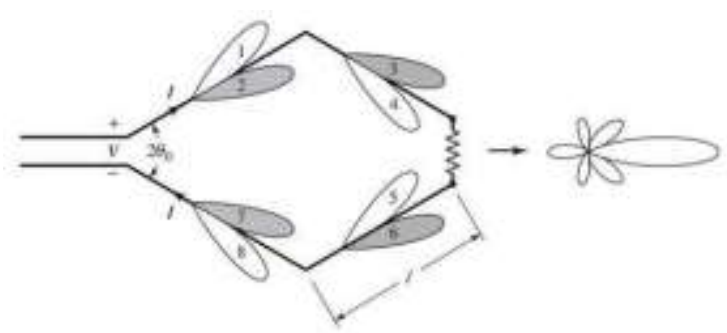

Gambar 1. Antena Rhombic yang Dibentuk dari Dua Antena V [1]

Sebuah antena memiliki elemen dan setiap elemen memiliki dimensi ukuran. Salah satu dimensi ukuran sebuah antena adalah panjang elemen antena (L). Panjang elemen ( L) adalah salah satu bagian yang mempengaruhi pola radiasi yang akan dihasilkan dalam rancangan sistem antena Rhombic. Berikut adalah persamaan untuk menghitung panjang elemen antena:

$$
\begin{aligned}
& L=\frac{\lambda}{2 \sin ^{2} A} \\
& \lambda=\frac{c}{f}
\end{aligned}
$$

Ketinggian suatu antena akan mempengaruhi pola radiasi dan gain yang akan dihasilkan. Sebelum merancang sebuah antena, persamaan berikut dapat digunakan untuk menghitung ketinggian antena:

$$
H=\frac{\lambda}{4 \sin A}
$$

Dimana :

$\mathrm{L}=$ Panjang Elemen (meter)

$\lambda=$ Panjang Gelombang (meter)

$\mathrm{A}=$ Sudut Antara Elemen Antena

$\mathrm{c}=$ Kecepatan Cahaya $\left(3 \times 10^{8}\right.$ meter/detik $)$

$f=$ Frekuensi (Hertz)

$\mathrm{H}=$ Ketinggian Antena (meter)

Antena Rhombic berbentuk belah ketupat yang terdiri dari 4 elemen yang saling berhubungan keempat ujungnya. Pertemuan dari keempat elemen tersebut membentuk sudut (A). Sudut antara elemen juga mempengaruhi pola radiasai dan gain yang akan dihasilkan.

\section{B. Voltage Standing Wave Ratio (VSWR)}

VSWR adalah perbandingan antara minimum (|v|min) dengan amplitudo gelombang berdiri (standing wave) maksimum (|v|max). Saluran transmisi memiliki dua komponen gelombang tegangan, yaitu tegangan yang dikirimkan $\left(\mathrm{v}_{+}\right)$dan tegangan yang direfleksikan ( $\left.\mathrm{v}_{-}\right)$. Pebandingan tegangan yang direfleksikan dengan yang dikirimkan disebut sebagai koefisien refleksi tegangan $(\Gamma)$.

$$
\frac{v_{-}}{v_{+}}=\frac{z_{L}-z_{0}}{z_{L}+z_{0}}
$$

Koefisien refleksi tegangan $(\Gamma)$ mempunyai nilai kompleks, yang menggambarkan besarnya magnitud dan fasa dari refleksi. Dimana $\mathrm{z}_{\mathrm{L}}$ adalah impedansi beban (load) dan $\mathrm{z}_{0}$ adalah impedansi saluran lossless. Sedangkan untuk mencari nilai VSWR dapat menggunakan persamaan berikut [1],

$$
\frac{\overline{|v|}}{\overline{|v|_{\max }}}=\frac{1+|\Gamma|}{1-|\Gamma|}
$$

Nilai dan kondisi yang ideal adalah ketika VSWR bernilai 1. Saat VSWR bernilai 1, dapat diartikan bahwa tidak ada refleksi ketika saluran dalam keadaan matching sempurna. Namun, hal tersebut merupakan kondisi yang sulit untuk diperoleh. Sehingga, nilai standar VSWR yang diperbolehkan dalam perancangan antena adalah $\leq 2$.

\section{Return Loss}

Banyaknya daya yang hilang pada beban karena tidak kembalinya daya yang dipantulkan dapat ditentukan dari nilai return loss. Besar return loss bisa didapatkan dari nilai perbandingan antara amplitudo dan gelombang yang direfleksikan serta yang dikirim. Selain VSWR, return lost juga dapat menjadi penentu apakah suatu perangkat transmitter dengan antena tersebut matching.

\section{Impedansi Input}

Rasio perbandingan antara tegangan dan arus pada sebuah terminal di antena atau rasio komponen dari medan listrik ke medan magnet pada suatu titik disebut dengan impedansi input. Impedansi input antena umumnya merupakan fungsi frekuensi. Dengan demikian antena akan disesuaikan dengan interkoneksi saluran transmisi dan perangkat. Selain itu, impedansi input antena dapat dipengaruhi oleh beberapa faktor, seperti: geometri, metode eksitasi, dan jarak dengan objek di sekitarnya [1].

\section{E. Received Signal Strength Indicator (RSSI)}

Indikator yang dapat digunakan oleh interface antena penerima sebagai acuan seberapa besar kuat sinyal adalah RSSI. RSSI merupakan nilai indeks yang diperlukan untuk menganalisis pola posisi [10]. Dengan memanfaatkan nilai indeks tersebut, posisi dapat diprediksi dan dapat diketahui apakah antena penerima dan pengirim masih dapat berkomunikasi. Dari nilai indeks RSSI, kekuatan sinyal (dalam dBm) sebuah antena dapat diketahui. Dengan menggunakan persamaan berikut, nilai RSSI hasil pengukuran dapat diubah menjadi kuat sinyal.

$$
\text { signal }_{d B m}=(R S S I / 1.9)-127
$$

Berdasarkan [10], nilai RSSI dapat dimodelkan dan diprediksi berdasarkan kuat sinyal rata-rata dari jarak radius penerima. Nilai RSSI tersebut dapat dicari menggunakan 
persamaan berikut:

$$
R_{d B I}=A-10 n \log d
$$

Sehingga, berdasarkan (7), nilai path loss exponent dapat dihitung dengan menggunakan persamaan di bawah ini:

$$
n=\frac{A-R S S I d B m}{10 \log d}
$$

Dimana:

$\mathrm{n}=$ Konstanta propagasi sinyal (path loss exponent)

$\mathrm{A}=$ Kekuatan sinyal yang diterima dalam jarak 1 meter $(\mathrm{dBm})$

$\mathrm{d}=$ Jarak dari pengirim (meter)

Nilai $\mathrm{n}$ dari path loss exponent setiap kondisi lingkungan berbeda-beda, tabel 1 di bawah ini dapat menjadi referensi apabila ingin mengasumsikan nilai $\mathrm{n}$ (path loss exponent) berdasarkan kondisi lingkungan sekitar.

TABEL I

NILAI PATH LOSS EXPONENT BERDASARKAN KONDISI LINGKUNGAN [11]

\begin{tabular}{ll}
\hline \hline \multicolumn{1}{c}{ Enviroment } & PathLoss Exponent, $\mathrm{n}$ \\
\hline Free Space & 2 \\
Urban area cellular radio & $2,7-3,5$ \\
Shadowed urban cellular radio & $3-5$ \\
In Building line of sight & $1,6-1,8$ \\
Obstructed in building & $4-6$ \\
Obstructed in factories & $2-3$ \\
\hline \hline
\end{tabular}

\section{METODE}

Pembuatan antena Rhombic dilakukan dalam beberapa tahapan, yang diawali dengan perancangan untuk menentukan frekuensi kerja, dimensi, dan material yang digunakan. Tahap selanjutnya adalah fabrikasi hasil desain dan pengujian. Proses pengujian antena dilakukan terintegrasi pada sistem sistem aplikasi telemetri data, yang blok diagramnya dapat dilihat pada gambar 2.

\section{A. Desain Antena}

Desain antena Rhombic pada penelitian ini menggunakan aplikasi simulasi antena modeler dan optimizer 4nec2. Nilai hasil perhitungan parameter dimasukkan pada software 4nec2 untuk dilakukan simulasi. Dalam desain antena ini, frekuensi kerja yang diinginkan adaalah $433 \mathrm{MHz}$ dengan tujuan untuk dapat diaplikasikan pada teknologi telemetri pada balon udara atmosfer atau roket. Pada antena Rhombic terdapat beberapa parameter yang sangat mempengaruhi dalam desain, yaitu: tinggi antena $(\mathrm{H})$, panjang elemen antena $(\mathrm{L})$, dan sudut antar elemen (A).

Untuk mencari nilai panjang elemen antena, panjang gelombang harus dicari terlebih dahulu. Dengan menggunakan (2), dimana frekuensi kerja telah ditetapkan yaitu $433 \mathrm{MHz}$, maka didapatkan panjang gelombang sebesar $69,28 \mathrm{~cm}$. Selanjutnya, nilai panjang elemen antena bisa kita dapatkan menggunakan persamaan (1) dengan nilai $\mathrm{A}=45^{\circ}$. Nilai panjang elemen antena yang didapatkan yaitu $\mathrm{L}=34,7 \mathrm{~cm}$. Sehingga secara keseluruhan, hasil perhitungan dapat dilihat pada tabel 2, dan desain hasil simulasi ditunjukkan pada gambar 3 di berikut ini.

TABEL II

Nilai Parameter Antena Rhombic Hasil Perhitungan

\begin{tabular}{clc}
\hline \hline Konstanta & \multicolumn{1}{c}{ Parameter } & Nilai \\
\hline$L$ & Panjang lengan rhombik & $34,7 \mathrm{~cm}$ \\
$2 \varphi(A)$ & Sudut antara lengan rhombik & $90^{\circ}$ \\
$D$ & Diameter kawat & $4 \mathrm{~mm}$ \\
\hline \hline
\end{tabular}

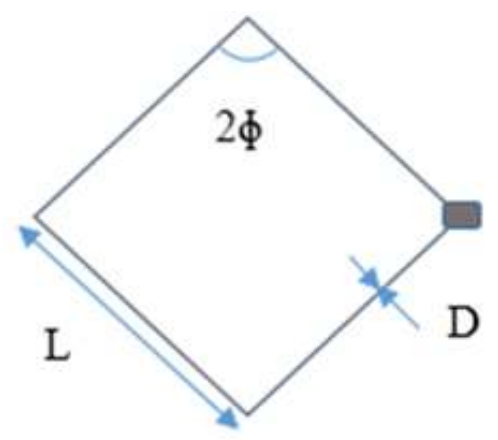

Gambar 3. Hasil Desain Antena Rhombic Menggunakan Software 4nec2

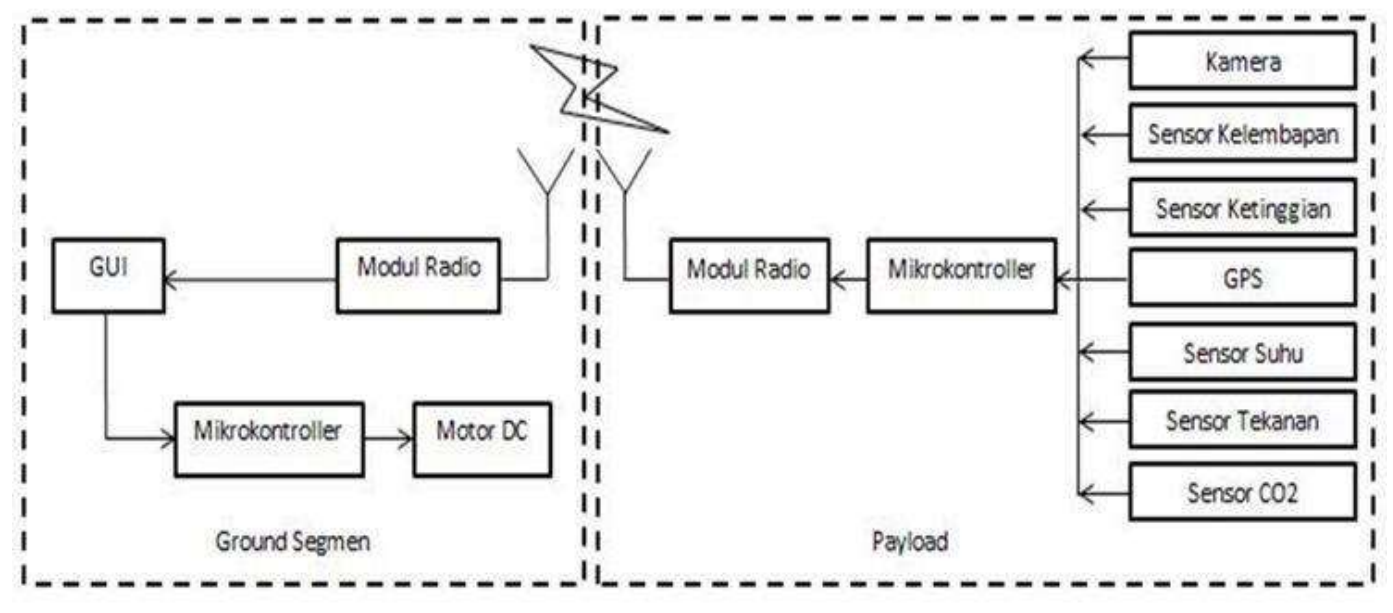

Gambar 2. Blok Diagram Sistem Aplikasi Telemetri Data 


\section{B. Fabrikasi Antena}

Antena difabrikasi berdasarkan hasil desain yang telah dihitung dan disimulasikan. Antena Rhombic ini difabrikasi menggunakan material kawat tembaga dan dua pipa plastik atau pvc sebagai tiang penyangga. Konektor antena yang digunakan adalah jenis N-Konektor. Untuk kabel, yang digunakan pada antena adalah jenis pigtail. Jenis ini dapat menyesuaikan slot antenna. Sedangkan konektor yang digunakan pada kabel adalah tipe N-Male to RP-SMA. Hasil fabrikasi antena Rhombic dapat dilihat pada gambar 4 (a) untuk antena dan kabel konektor, dan (b) untuk antena yang terintegrasi sistem tracking.

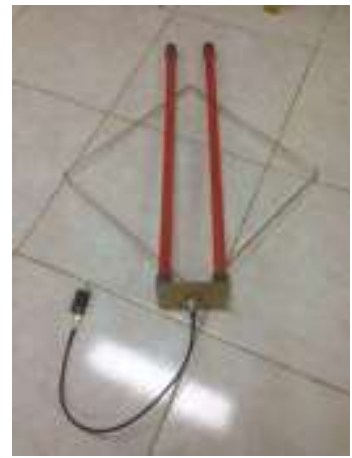

(a)

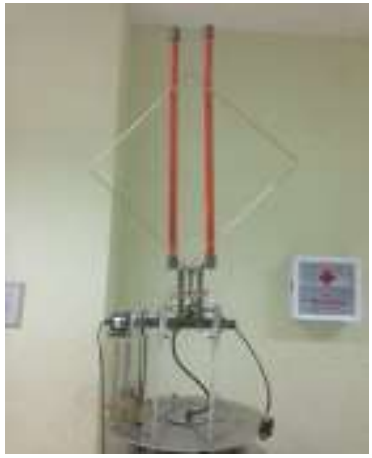

(b)
Gambar 4. Hasil Fabrikasi (a) Antena Rhombic dan Kabel Konektor, (b) Antena Rhombic Terintegrasi Sistem Tracking

\section{Pengujian Antena}

Proses pengujian antena Rhombic hasil fabrikasi, dilakukan dengan dua cara yaitu pengukuran menggunakan instrumen pengukuran dan pengujian outdoor secara langsung. Pengujian dengan instrumen pengukuran dilakukan menggunakan perangkat Keysight M9371A PXIe Vector Network Analyzer yang dapat bekerja pada rentang frekuensi $300 \mathrm{kHz}$ hingga 6,5 GHz. Parameter yang diukur menggunakan instrumen pengukuran ini adalah VSWR, return loss, dan impedansi. Sedangkan pengukuran secara langsung, dilakukan di luar ruangan menggunakan Graphic User Interface (GUI) Radiosonde yang merupakan aplikasi dari sistem telemetri data. Pengukuran dilakukan dari rooftop Gedung Prof. Mohammad Nasir lantai 13 Politeknik Negeri Batam ke kawasan wisata Ocarina Batam Center. Data yang dikirimkan pada pengukuran adalah data GPS, suhu, kelembaban udara, tekanan udara, kecepatan angin, dan arah angin.

\section{HASIL DAN PEMBAHASAN}

\section{A. Pengukuran Menggunakan Instrumen}

Setelah antena Rhombic difabrikasi, pengukuran yang pertama kali dilakukan adalah pengukuran nilai VSWR. Pengukuran ini dilakukan menggunakan instrumen Vector Network Analyzer pada Laboratorium Radio Frekuensi (RF) Teaching Factory Manufacturing of Electronics (TFME) Politeknik Negeri Batam. Hasil Pengukuran nilai VSWR disajikan pada gambar 5 dan gambar 6.
Berdasarkan hasil pengukuran yang disajikan pada gambar 5, nilai VSWR optimum dari antena Rhombic adalah sebesar 1,53 pada frekuensi 416,743 MHz. Hasil tersebut menunjukkan bahwa pada frekuensi kerja $416,743 \mathrm{MHz}$, antena masih memenuhi kriteria dengan nilai $\mathrm{VSWR} \leq 2$. Selanjutnya, apabila antena diukur pada frekuensi $433,178 \mathrm{MHz}$ yang ditunjukkan pada gambar 6, maka didapatkan nilai VSWR sebesar 3,49. Antena hasil fabrikasi belum memenuhi harapan jika kita bandingkan dengan hasil perhitungan dan simulasi. Hal tersebut disebabkan oleh beberapa faktor, diantaranya yaitu: pengelasan dan penyolderan antena yang kurang baik.

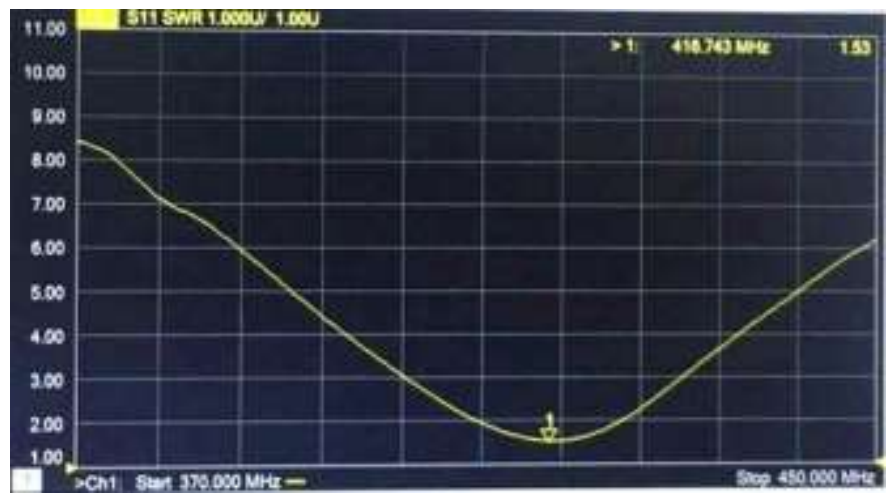

Gambar 5. Hasil Pengukuran Nilai VSWR pada Frekuensi 416,743 MHz (Optimum)

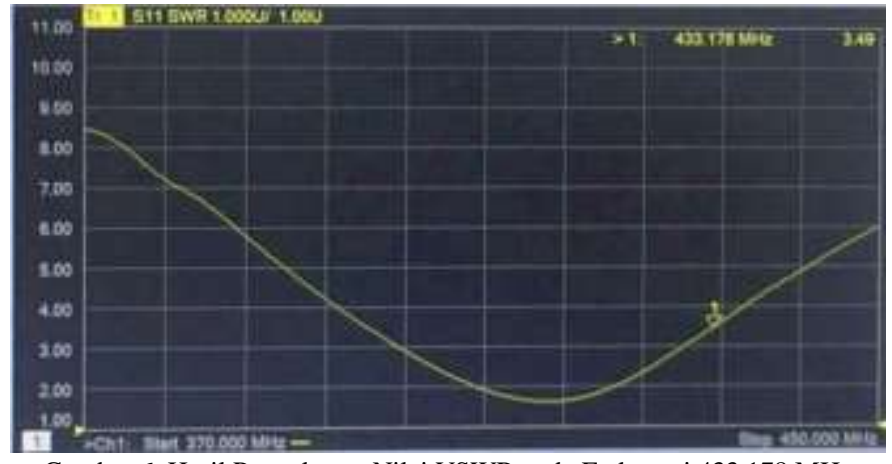

Gambar 6. Hasil Pengukuran Nilai VSWR pada Frekuensi 433,178 MHz

Pengukuran pada antena Rhombic selanjutnya adalah pengukuran return loss. Parameter ini dapat menjadi penentu matching atau tidaknya suatu perangkat transmitter dengan antena. Pada frekuensi 433,178 MHz, nilai return loss yang terukur adalah $-5,07 \mathrm{~dB}$. Hasil pengukuran return loss pada frekuensi 433,178 MHz ditunjukkan pada gambar 7 . 


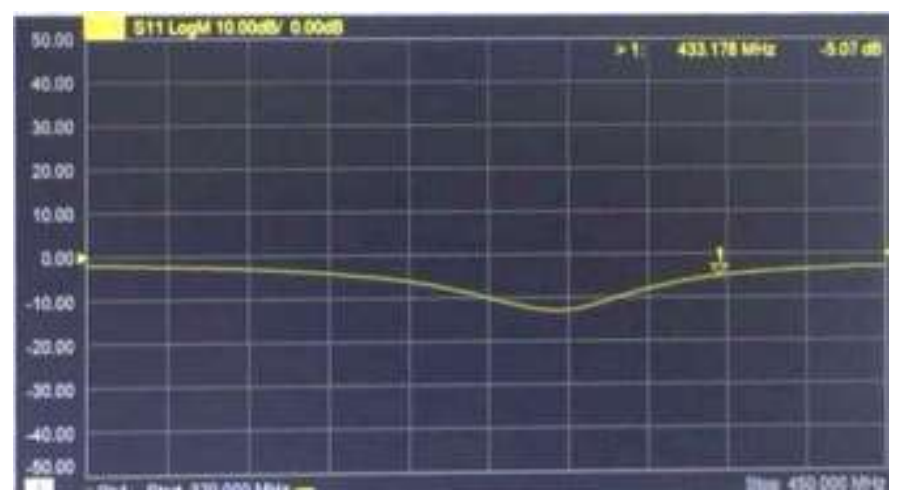

Gambar 7. Hasil Pengukuran Nilai Return Loss pada Frekuensi 433,178 MHz

Antena Rhombic hasil fabrikasi ini memberikan nilai return loss paling baik jika diukur pada frekuensi 416,743 MHz. Disajikan pada gambar 8, nilai return loss pada frekuensi $416,743 \mathrm{MHz}$ adalah $-13,45 \mathrm{~dB}$. Nilai return loss tersebut dianggap cukup baik karena berada di bawah $-9,54 \mathrm{~dB}$, sehingga dapat disimpulkan bahwa nilai gelombang yang direfleksikan tidak terlalu besar jika dibandingkan dengan gelombang yang dikirimkan.

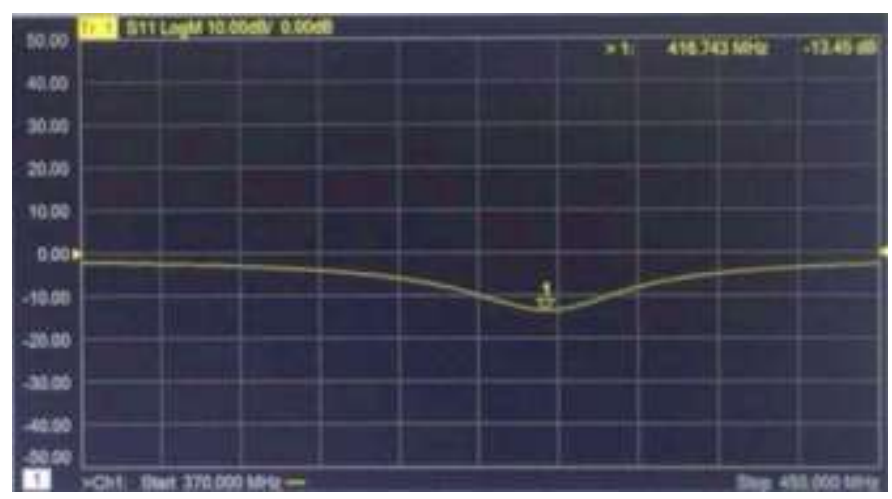

Gambar 8. Hasil Pengukuran Nilai Return Loss pada Frekuensi 416,743 MHz

Grafik impedansi antena hasil pengukuran disajikan dalam bentuk smithchart. Grafik tersebut merupakan fungsi frekuensi yang diperoleh dengan perhitungan matematis. Berikut gambar 9 dan 10 merupakan hasil pengukuran impedansi antena Rhombic yang diukur menggunakan Vector Network Analyzer.

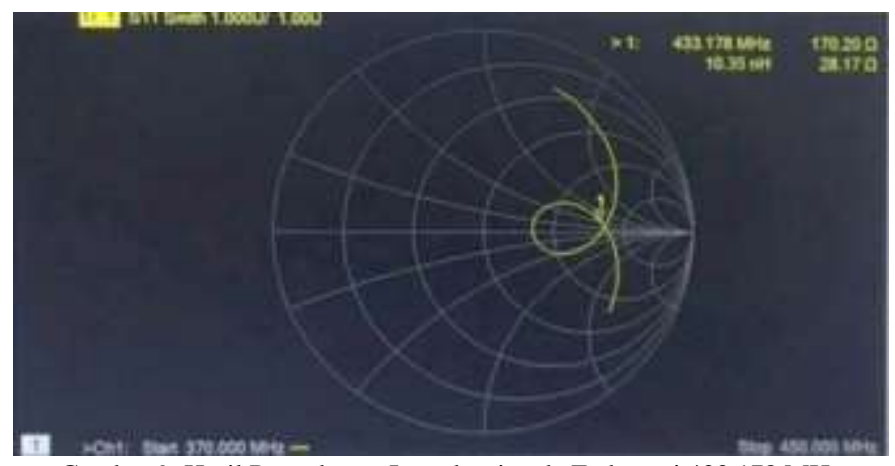

Gambar 9. Hasil Pengukuran Impedansi pada Frekuensi 433,178 MHz

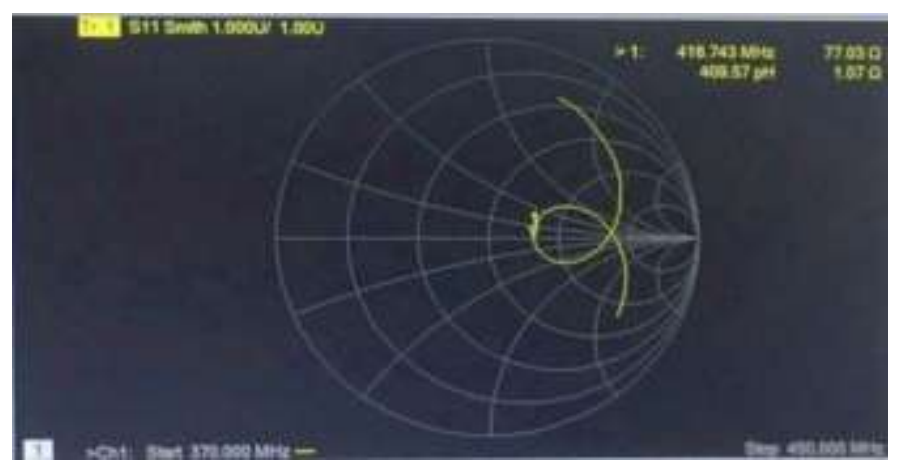

Gambar 10. Hasil Pengukuran Impedansi pada Frekuensi 416,743 MHz

Pada gambar 9 ditunjukkan bahwa nilai impedansi pada frekuensi 433,178 MHz adalah 170,05+j28,17 $\Omega$. Lebih lanjut, pada gambar 10, nilai impedansi pada frekuensi $416,743 \mathrm{MHz}$ atau pada frekuensi optimum antena Rhombic yaitu $77,03+\mathrm{j} 1,07 \Omega$. Berdasarkan kedua hasil pengukuran tersebut, masih terdapat selisih yang cukup signifikan dari nilai impedansi yang diinginkan, yaitu $50 \Omega$. Selisih ini dapat mengakibatkan banyak daya yang dipantulkan kembali dan menurunkan nilai return loss. Dari pengukuran ini, dapat disimpulkan terjadinya pergesaran atau missmatch pada antena hasil fabrikasi. Solusi dari selisih nilai impedansi, salah satunya, adalah dengan menggunakan rangkaian matching impedance.

Berdasarkan hasil pengukuran dari antena Rhombic yang telah difabrikasi, dapat dilihat pada tabel 3, bahwa beberapa parameter hampir memenuhi spesifikasi awal. Namun, dari hasil fabrikasi antena Rhombic terdapat beberapa parameter yang belum sesuai dengan perancangan awal.

TABEL III

NiLAi Perbandingan SpesifiKasi Awal, SimUlasi, DAN Hasil FabriKaSI ANTENA RHOMBIC

\begin{tabular}{|c|c|c|c|c|}
\hline Parameter & $\begin{array}{c}\text { Spesifikasi } \\
\text { Awal }\end{array}$ & Simulasi & Hasil Fabrikasi & Keterangan \\
\hline Frekuensi & $\begin{array}{l}433-436 \\
\mathrm{MHz}\end{array}$ & $\begin{array}{l}433 \\
\mathrm{MHz}\end{array}$ & $\begin{array}{l}\text { 416,743 MHz } \\
\text { (optimum) }\end{array}$ & $\begin{array}{l}\text { Masuk dalam } \\
\text { rentang frekuensi } \\
\text { antena pemancar } \\
\text { pada modul radio } \\
\text { 3DR }(414 \mathrm{MHz}- \\
454 \mathrm{MHz})\end{array}$ \\
\hline VSWR & $\leq 2$ & 1,77 & $\begin{array}{l}3,49(433,178 \\
\mathrm{MHz}) \\
1,53(416,743 \\
\mathrm{MHz})\end{array}$ & $\begin{array}{l}\text { VSWR } \leq 2 \text { adalah } \\
\text { rasio yang di } \\
\text { perbolehkan }\end{array}$ \\
\hline Return Loss & NA & NA & $\begin{array}{l}-5,07 \mathrm{~dB} \\
(433,178 \\
\mathrm{MHz}) \\
-13,45 \mathrm{~dB} \\
(416,743 \\
\mathrm{MHz})\end{array}$ & $\begin{array}{l}\text { Untuk frekuensi } \\
\text { optimum masih } \\
\text { memenuhi (< } \\
-9,54 \mathrm{~dB})\end{array}$ \\
\hline
\end{tabular}




\begin{tabular}{|c|c|c|c|c|}
\hline Parameter & $\begin{array}{c}\text { Spesifikasi } \\
\text { Awal }\end{array}$ & Simulasi & Hasil Fabrikasi & Keterangan \\
\hline Impendansi & $50 \Omega$ & $50 \Omega$ & $\begin{array}{l}170,05+\mathrm{j} 28,17 \\
\Omega(433,178 \\
\mathrm{MHz}) \\
77,03+\mathrm{j} 1,07 \Omega \\
(416,743 \\
\mathrm{MHz})\end{array}$ & $\begin{array}{l}\text { Dibutuhkan } \\
\text { rangkaian } \\
\text { matching } \\
\text { impedance }\end{array}$ \\
\hline
\end{tabular}

Ada beberapa faktor yang menyebabkan belum sesuainya hasil fabrikasi dengan perancangan awal, seperti: pengelasan atau penyolderan antena yang kurang baik, proses pembengkokan kawat tembaga tidak presisi, dan pengaruh konektor [12]. Walaupun demikian, antena Rhombic masih dapat digunakan sebagai antena penerima untuk aplikasi telemetri data karena antena pemancar pada modul radio 3DR menggunakan frekuensi kerja pada rentang $414 \mathrm{MHz}-454$ MHz. Sehingga, pengujian secara langsung (outdoor) diasumsikan masih dapat dilakukan karena masih berada pada frekuensi kerja antena pengirim.

\section{B. Pengujian Langsung (Outdoor)}

Pengujian akhir dari hasil fabrikasi antena Rhombic adalah pengujian secara langsung yang dilakukan dengan dua skenario. Skenario pertama adalah pengujian pada lingkungan kampus hingga jarak kurang lebih 600 meter. Proses pengukuran dilakukan dengan cara payload yang terdapat di dalamnya modul radio 3DR bergerak menjauh dari antena penerima (antena Rhombic) yang terintegrasi dengan aplikasi telemetri data. Saat payload bergerak menjauh, dilakukan pengambilan data RSSI untuk mengetahui kuat sinyal dan data lingkungan (ketinggian, temperatur, dan GPS) untuk mengetahui sistem masih saling terhubung. Disajikan pada gambar 11, dapat dilihat perbandingan kuat sinyal RSSI (dalam $\mathrm{dBm}$ ) antara pengujian dan perhitungan. Perhitungan kuat sinyal RSSI (dalam $\mathrm{dBm}$ ) dilakukan dengan menggunakan persamaan (7) dan asumsi nilai pathloss exponent $\mathrm{n}=2$. Nilai tersebut berdasarkan referensi pada tabel 2 , dengan asumsi bahwa pengujian dilakukan dalam kondisi free space.

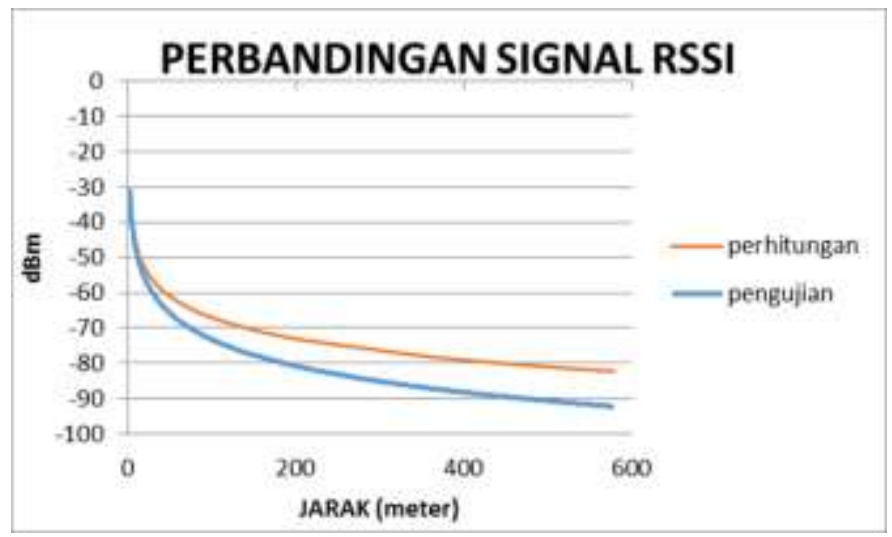

Gambar 11. Perbandingan Sinyal RSSI (dalam dBm) Hasil Pengujian dan Perhitungan
Hasil pengujian pada gambar 11 di atas menunjukkan bahwa semakin jauh jarak payload dengan antena penerima maka sinyal akan semakin melemah hingga mencapai -85.95 $\mathrm{dBm}$. Apabila kuat sinyal semakin mendekati nol, maka sensitifitas sinyal semakin tinggi. Pada datasheet modul 3DR radio telemetri yang digunakan adalah nilai sensitifitas sebesar $-117 \mathrm{dBm}$. Sehingga, jika kuat sinyal melebihi nilai sensitifitas pada modul radio 3DR akan mengakibatkan data tidak dapat terkirim dan disconnected.

Skenario yang kedua adalah dengan mencari jarak maksimum jangkauan dari antena hasil fabrikasi. Hasil pengukuran didapatkan jangkauan hingga sejauh 3,49 meter, yaitu dari lantai 13 Gedung Prof. Mohammad Nasir (Tower A) Politeknik Negeri Batam ke Ocarina Batam. Titik pengukuran horizontal dan vertikal disajikan pada gambar 12 (a) dan (b). Pada jarak tersebut payload masih terkoneksi dan dapat mengirimkan keseluruhan data parameter lingkungan.

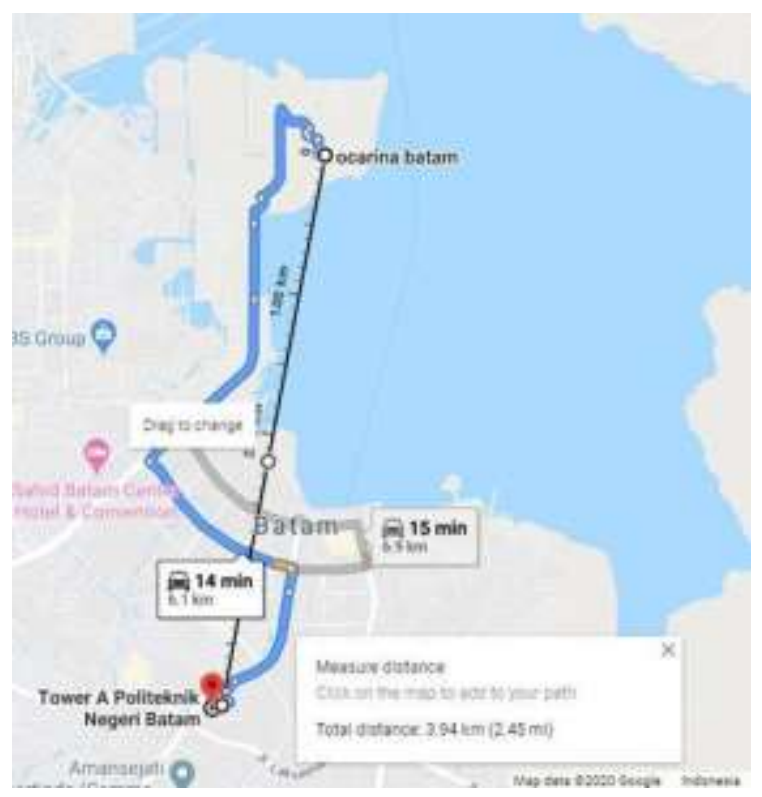

(a)

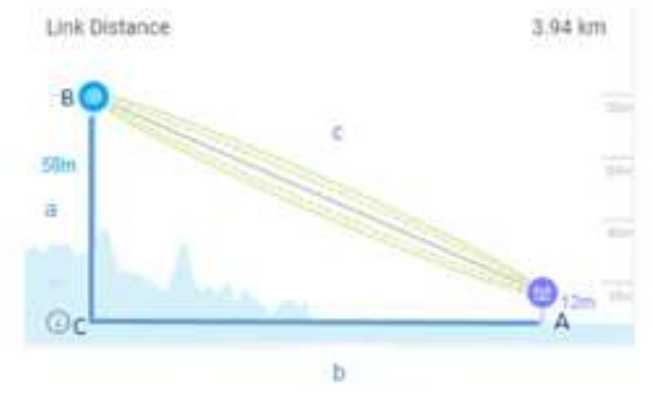

(b)

Gambar 12. Titik Pengukuran RSSI dari Tower A Politeknik Negeri Batam ke Ocarina Batam (a) Horizontal, (b) Vertikal Link Distance 


\section{KESIMPULAN}

Kesimpulan yang dapat diambil dari penelitian ini adalah antena Rhombic untuk antena penerima pada aplikasi telemetri data berhasil difabrikasi. Hasil fabrikasi antena menunjukkan bahwa frekuensi optimum antena berada pada frekuensi 416,743 MHz. Pada frekuensi tersebut, antena memiliki nilai VSWR sebesar 1,53 atau masuk dalam kriteria nilai $1 \leq$ $\mathrm{VSWR} \leq 2$. Antena memiliki nilai return loss $-13,45 \mathrm{~dB}$, sehingga secara keseluruhan menunjukkan bahwa antena masih memenuhi kriteria. Antena juga berfungsi secara baik karena antena pemancar pada modul radio 3DR bekerja pada rentang frekuensi $414 \mathrm{MHz}-454 \mathrm{MHz}$. Antena hasil fabrikasi ini dapat berkomunikasi hingga jarak 3,94 kilometer tanpa penghalang atau dalam kondisi Line of Sight (LOS). Secara umum, antena Rhombic hasil fabrikasi bekerja dengan baik pada frekuensi optimum, namum masih terdapat ruang untuk dilakukan perbaikan dan pengembangan kedepannya.

\section{REFERENSI}

[1] C. A. Balanis, Antenna Theory: Analysis and Design. John Wiley \& Sons, 2016.

[2] "Advantages of Rhombic antenna | disadvantages of Rhombic antenna."

world.com/Terminology/Advantages-and-Disadvantages-of-

Rhombic-antenna.html (accessed May 14, 2020).

[3] N. K. Darimireddy, R. R. Ramana, N. Rajasekhar, and P. SrinivasaRao, "Rhombic Slotted Pentagonal Patch Antenna for GPS Applications," in 2018 IEEE Indian Conference on Antennas and Propogation (InCAP), Dec. 2018, pp. 1-4. doi: 10.1109/INCAP.2018.8770830.

[4] N. A. Eltresy, H. A. Malhat, and S. H. Zainud-Deen, "A rhombic nanoantenna for infrared detection applications," in 2017 34th
National Radio Science Conference (NRSC), Mar. 2017, pp. 9-14. doi: 10.1109/NRSC.2017.7893461.

[5] K. K. A. John and T. Mathew, "Rhombic Split Ring Resonator (RSRR) RFID tag for UHF band," in 2016 Progress in Electromagnetic Research Symposium (PIERS), Aug. 2016, pp. 5179-5182. doi: 10.1109/PIERS.2016.7735868.

[6] H. Nornikman, B. H. Ahmad, Z. Zakaria, N. E. S Ramlee, M. Z. A Abd Aziz, and M. K. Ismail, "Multiband Minkowski Fractal Patch Antenna with Rhombic SRR for Wireless LAN and WiMAX Applications," in 2018 IEEE International RF and Microwave Conference (RFM), Dec. 2018, pp. 85-88. doi: 10.1109/RFM.2018.8846542.

[7] S. Aisyah, D. Untari, and H. Wijanarko, "Design of Data Acquisition System of Environmental Parameter in Riau Islands using myRIO," in 2019 2nd International Conference on Applied Engineering (ICAE), Oct. 2019, pp. 1-6. doi: 10.1109/ICAE47758.2019.9221689.

[8] S. Aisyah, M. L. Prasetyo Nugroho, Kamarudin, and H. Wijanarko, "Image Transmission Performance Over UHF Channel Using Real Time Processing in LOS and NLOS Transmission," in 2019 2nd International Conference on Applied Engineering (ICAE), Oct. 2019, pp. 1-6. doi: 10.1109/ICAE47758.2019.9221658.

[9] H. Wijanarko, M. Hanif, S. Aisyah, and K. Kamarudin, "Desain dan Implementasi Antena Quadrifilar Helix untuk Komunikasi Antarpulau pada Pita UHF," Jurnal Rekayasa Elektrika, vol. 16, no. 2, Art. no. 2, Aug. 2020, doi: 10.17529/jre.v16i2.15486.

[10] S. Joana Halder and W. Kim, "A Fusion Approach of RSSI and LQI for Indoor Localization System Using Adaptive Smoothers," Journal of Computer Networks and Communications, vol. 2012, pp. 1-10, 2012.

[11] F. J. Casadevall Palacio et al., "Radio environmental maps: information models and reference model. Document number D4.1," Apr. 2011, Accessed: May 11, 2020. [Online]. Available: https://upcommons.upc.edu/handle/2117/14940

[12] Soni Aulia Rahayu, Ginaldi Ari Nugroho, Tiin Sinatra, Edy Maryadi, and Sartika, "Perancangan Antena Quadrifilar Helix untuk Pengukuran Parameter Atmosfer," in SIPTEKGAN XXI-2017, Serpong, Tangerang, Banten, Desember 2017, pp. 232-241. 